\title{
Low Back Pain Among Nurses Working at Public Hospitals in Eastern Ethiopia
}

This article was published in the following Dove Press journal:

Journal of Pain Research

\author{
Gelana Fekadu Mijena (D) \\ Biftu Geda $\mathbb{D}^{2}$ \\ Merga Dheresa (1) \\ Sagni Girma Fage $\mathbb{D}^{\prime}$
}

'School of Nursing and Midwifery, College of Health and Medical Sciences, Haramaya University, Harar, Ethiopia; ${ }^{2}$ Department of Nursing, College of Health and Medical Sciences, Meda Welabu University, Bale-Robe, Ethiopia

Correspondence: Sagni Girma Fage School of Nursing and Midwifery, College of Health and Medical Sciences, Haramaya University, P.O. Box 235, Harar, Ethiopia, Tel +251919231902

Email giruu06@gmail.com
Objective: This study assessed the prevalence of low back pain and factors associated with it among nurses working at public hospitals in eastern Ethiopia.

Materials and Methods: Institutional-based cross-sectional study was conducted from February 1 to March 20, 2018 among randomly selected 404 nurses working in public hospitals of Harari region and Dire Dawa city administration. Six trained nurses collected the data through a self-administered data collection technique. All variables that yield $\mathrm{p}<$ 0.25 in bivariable logistic regression were subjects for multivariable logistic regression analysis. The direction and strength of statistical association were measured by odds ratio with the corresponding 95\% confidence interval (CI). Finally, statistical significance was declared at $\mathrm{p}<0.05$.

Results: The 12-month prevalence of low back pain was $38.1 \%$ [95\% CI: $32.7-42.7 \%$ ]. It was more prevalent among females (65\%). More than 5 years of work experience [adjusted odds ratio $(\mathrm{AOR})=3.135 ; 95 \%$ CI (1.292-7.605)], manual lifting of weight $>10 \mathrm{~kg}$ $[\mathrm{AOR}=5.260 ; 95 \% \mathrm{CI}(1.869-14.805)]$ and working in awkward posture $[\mathrm{AOR}=3.93 ; 95 \%$ CI (1.109-13.924)] were variables significantly associated with low back pain among nurses. Conclusion: About two in five nurses working at public hospitals in Harari region and Dire Dawa city administration were suffering from low back pain. So, tailored intervention is needed to prevent nurses from further injury and retain experienced nurses.

Keywords: low back pain, nurses, public hospitals, eastern Ethiopia

\section{Introduction}

Low back pain (LBP) is a common cause of morbidity among healthcare workers of which nurses are highly vulnerable due to the nature of their physically demanding job. ${ }^{1}$ Nurses lift and transport patients, or heavy equipment usually in difficult environment especially in developing countries where lifting aides are very scarce or unavailable at all. ${ }^{2}$ Low back pain affects nurses' health as well as the quality of the care they provide. ${ }^{3}$ It is the most prevalent musculoskeletal disorder, affecting $28-47.7 \%$ of the dental personnel ${ }^{4}$ and $50-85 \%$ of adult population at some point in their lifetime. ${ }^{5-8}$

According to the US burden of disease collaborators, of all diseases and injuries contributing to disability-adjusted life years, low back pain is ranked third and it is the major cause of activity limitation among people below 45 years old. ${ }^{5}$ Moreover, it is ranked as the fifth cause of admission to hospital and the third cause of surgical procedures. ${ }^{6}$ Furthermore, loss of experienced staff due to such occupational injury has not been estimated. ${ }^{7}$ Sixteen percent sick leave days, which accumulates to a loss of 28 to 146 million working days annually, is attributed to low back pain. ${ }^{1,8}$ It also results 
in many consequences on activities of daily living such as walking, sleeping and getting out of bed. ${ }^{9}$ On the other hand, deterioration in nurses' health could also affect patient care delivery. $^{10}$

In some Asian countries, more than half (54.4\%) of nurses are absent from their job by sick leave due to low back pain ${ }^{11}$ while $10 \%$ of them left their work at least for a week within three months. Nearly $44 \%$ could not perform their job properly because of LBP, whereas one-third became less productive and creative, and a quarter of respondents reported that it decreased the quality of care they provide to the patient. ${ }^{12}$ In the world, the prevalence of LBP among nurses was variably reported from different countries and settings. Hence, it was $73-76 \%$ in Switzerland, ${ }^{13} 62 \%$ in Dutch, ${ }^{14} 33-86 \%$ in Italy, ${ }^{15}$ $65.8 \%$ in Turkey, ${ }^{16} 90.3 \%$ in South Korea, ${ }^{17} 78 \%$ in Nepal, ${ }^{12}$ $63.1 \%$ in Malaysia, ${ }^{8} 54.3 \%$ in Qatar, ${ }^{9} 48.4-74.2 \%$ in Saudi Arabia, ${ }^{11,18,19} 74.5 \%$ in Yemen, ${ }^{20} 73.5-77.19 \%$ in Nigeria, ${ }^{3,21,22} 79.3 \%$ in Egypt, ${ }^{23} 78 \%$ in Rwanda, ${ }^{24} 57.7 \%$ in Tunisia, ${ }^{25}$ and $45.8-60 \%$ in Ethiopia so far. ${ }^{3,26,27}$

Nurse's experience of low back pain is related to the nature of their job and influenced by different factors. Literatures unveiled that socio-demographic factors such as age, being female, married, longer years of work experience were associated with LBP among nurses. ${ }^{3,19,23-25}$ Moreover, lifestyle factors including smoking, chewing khat and physical activity ${ }^{16,20,25,26}$ have been identified as substantially affecting the development of LBP. Studies have also indicated workplace conditions like standing and sitting for a long time, working in awkward posture, night shifts, lifting heavyweight greater than $10 \mathrm{~kg}$, transferring and repositioning the patient, and working units were risk factors for LBP. ${ }^{12,18,20,21,23,27,28}$

Even though studies were conducted on the prevalence and risk factors of low back pain, epidemiologically reliable evidence among nurses with adequate sample size was not well documented. Thus, this study aimed to identify prevalence and factors associated with low back pain among nurses working in public hospitals of Harari region and Dire Dawa city administration, eastern Ethiopia.

\section{Materials and Methods}

\section{Study Setting and Period}

The study was conducted from February 1 to March 20, 2018, in four public hospitals: two hospitals in Harari region (Hiwot Fana Specialized University Hospital and Jugel Hospital), and two hospitals (Dilchora Referral Hospital and Sabian Primary Hospital) situated in Dire Dawa city administration. Harari region and Dire Dawa city administration are located on the distance of $526 \mathrm{~km}$ and $515 \mathrm{~km}$ respectively from Addis Ababa in eastern Ethiopia.

\section{Study Design and Population}

Institutional-based cross-sectional study design was used. All nurses working at public hospitals in Harar town and Dire Dawa city administration were source populations while the study populations were all nurses selected randomly by lottery method from among those working at each hospital. Nurses on sick leave, study leave and annual leave during the study period were excluded.

\section{Sample Size and Sampling Procedure}

The sample size was determined by using Epi-Info 7 with the assumptions of two-sided confidence level $95 \%$, power $=80 \%$ and ratio of exposed (those who felt little pleasure and reported to have $\mathrm{LBP}=47.1 \%$ ) to unexposed (those who felt little pleasure and reported no LBP $=52.9 \%)^{27}$ of $1: 1$ and by adding 5\% non-response rate. The final sample size was found to be 419 nurses. The sample size was proportionally allocated to those four public hospitals. The study participants were selected by simple random sampling through the lottery method using their list from the each hospital's human resource department as a sampling frame. After identifying study participants, we approached the nurses individually in person, informed the purposes and procedures of the study and that he/she is randomly selected to participate if willing. The data collection was done accordingly after obtaining the participants' consent to participate in the study.

\section{Data Collection Tool and Procedure}

English version of standard Nordic Musculoskeletal Questionnaire $^{29}$ with Visual Analog Scale (VAS) ${ }^{30}$ was used for this study. The questionnaires were comprised of socio-demographic information, lifestyle and personal factors, experience of LBP in the past 12 months and its duration using VAS. This visual analog scale contains a measuring label that ranges from 0 to 10 . Zero indicates no pain while 10 indicates the worst pain. The effect of LBP on activities of daily living contains six questions, work-related factors contain 13 questions and psychosocial factors contain 10 questions. Data were collected through self-administered technique by giving the questionnaires to the study participants to fill and return it back the next day. Six trained nurses collected the data. 


\section{Data Quality Control}

To assure the data quality, standardized and structured questionnaires were used. The data collectors and supervisors were given two days intensive training on the study tool and the data collection approach. Pre-test (a data collection to check the workability of the tool before the commencement of actual data collection) was done among $5 \%$ (21 nurses) of the final sample size at Haramaya district hospital, which is found midway between Dire Dawa city administration and Harar town. Data collectors provided a brief introductory orientation for the study participants. The entire data collection process was monitored and supervised by investigators. The completeness and logical consistency were checked and appropriate corrections were made accordingly.

\section{Data Processing}

We checked the data for completeness, entered into Epi data version 3.1 and exported to SPSS version 22 for analysis. We cleaned the data by running the frequency and cross-checking any missing variable from the hard copy. Descriptive statistics were used to present the prevalence of low back pain and the independent variables. Experience of low back pain was measured by questions with "yes" coded as 1 and "no" coded as 0 responses.

The intensity of LBP was measured as follows: Mild LBP: pain intensity with a score of 1 to 3 on VAS, Moderate LBP: pain intensity with a score of 4 to 6 on VAS, and Severe LBP: pain intensity with a score of 7 to 10 on VAS. ${ }^{30}$ Based on the duration LBP classified as; Acute LBP: the pain which lasts for less than six weeks, Sub-acute LBP: the pain which lasts for more than six weeks but less than 3 months, and chronic LBP: the pain which persists for more than 3 months. ${ }^{31}$ The psychosocial variables were collected using ordinal scale (excellent, very good, good, fair, poor) and re-coded into binary as good (excellent, very good and good) and poor (fair and poor).

\section{Statistical Analysis}

Binary logistic regression was used to check for the association between the outcome variable and the independent variables. Variables that yield p-value of $<0.25$ in bivariable analysis were considered as candidate for multivariable logistic regression analysis.

For measuring the strength of the association between the outcome and independent variables, crude odds ratio
(COR) and adjusted odds ratio (AOR) along with 95\% confidence interval (CI) were calculated. The fitness of the model was tested by Hosmer Lemeshow goodness of fit test, and accordingly the model was considered fit because it was insignificant or yield $p>0.05$. Finally, statistical significance was declared at $p$-value $<0.05$.

\section{Results}

\section{Socio-Demographic Characteristics of Participants}

Ninety-six percent (404) of the participants responded to the questionnaires. Two hundred twenty-five $(55.7 \%)$ were females, the respondents' age ranges from 20 to 60 years with the mean age of $30.4(\mathrm{SD} \pm 8.733)$. The dominant, 248 (61.4\%) participants belong to the $20-29$ age group. One in half of the respondents, $207(51.2 \%)$ were married, and majority of the study participants, 304 (75.2\%), were bachelor of science (BSc) degree holders. The mean years of work experience was $6.02( \pm 4.64 \mathrm{SD})$ (Table 1$)$.

\section{Lifestyle and Personal Characteristics of Participants}

Of the study participants, $106(26.2 \%)$ reported to have chronic diseases among which 44 (41.6\%), 29 (27.4\%), 17 $(16 \%)$, and $16(15 \%)$ accounts for hypertension, diabetes mellitus, arthritis and asthma, respectively. Significantly higher number of the participants 304 (75\%), 325 (80.4\%) and $365(90.3 \%)$ do not have habit of drinking alcohol, chewing khat and smoking cigarettes, respectively. Two hundred eighteen $(69.6 \%)$ did not have regular exercise habits. The majority of the study participants had the knowledge about back ergonomics 252 (62.4\%), even though only one-fourth 103 (25.5\%) had its practice (Table 2).

\section{Psychosocial Characteristics of Participants}

Majority of the participants, 245 (60.6\%) reported mental stress at work. Half of the participants $202(50 \%)$ reported to experience sleep disturbance related to their job (Table 3).

\section{Prevalence of LBP and Related Characteristics}

Out of 404 study participants; 154 (38.1\%) [95\% CI (32.7-42.7\%)] reported that they experienced low back pain in the past 12 months prior to the study period and the point prevalence was $36.4 \%$. Of those with low back pain; 100 
Table I Socio-Demographic Characteristics of Nurses Working at Public Hospitals in Harari Region and Dire Dawa City Administration, Eastern Ethiopia, $2018(n=404)$

\begin{tabular}{|c|c|c|c|}
\hline Variables & Category & Frequency & $\%$ \\
\hline Sex & $\begin{array}{l}\text { Female } \\
\text { Male }\end{array}$ & $\begin{array}{l}225 \\
179\end{array}$ & $\begin{array}{l}55.7 \\
44.3\end{array}$ \\
\hline Age & $\begin{array}{l}20-29 \\
30-39 \\
40 \text { and above }\end{array}$ & $\begin{array}{l}248 \\
93 \\
63\end{array}$ & $\begin{array}{l}61.4 \\
23 \\
15.6\end{array}$ \\
\hline $\begin{array}{l}\text { Marital } \\
\text { status }\end{array}$ & $\begin{array}{l}\text { Single } \\
\text { Married } \\
\text { Others }^{\mathrm{a}}\end{array}$ & $\begin{array}{l}179 \\
207 \\
18\end{array}$ & $\begin{array}{l}44.3 \\
51.2 \\
4.5\end{array}$ \\
\hline $\begin{array}{l}\text { Working } \\
\text { unit }\end{array}$ & $\begin{array}{l}\text { Medical ward } \\
\text { Surgical ward } \\
\text { Pediatrics ward } \\
\text { OPD } \\
\text { ICU } \\
\text { ORT } \\
\text { Emergency unit }\end{array}$ & $\begin{array}{l}54 \\
52 \\
39 \\
120 \\
41 \\
37 \\
60\end{array}$ & $\begin{array}{l}13.4 \\
12 \\
9.7 \\
29.7 \\
10.1 \\
9.2 \\
14.9\end{array}$ \\
\hline $\begin{array}{l}\text { Work } \\
\text { experience } \\
\text { in years }\end{array}$ & $\begin{array}{l}<5 \\
>5\end{array}$ & $\begin{array}{l}238 \\
166\end{array}$ & $\begin{array}{l}58.9 \\
41.1\end{array}$ \\
\hline $\begin{array}{l}\text { Educational } \\
\text { status }\end{array}$ & $\begin{array}{l}\text { Diploma ( } 3 \text { years college study) } \\
\text { Degree/BSc ( } 4 \text { years university } \\
\text { study) and above (masters with } \\
2 \text { years post graduate } \\
\text { university study) }\end{array}$ & $\begin{array}{l}95 \\
309\end{array}$ & $\begin{array}{l}23.5 \\
76.4\end{array}$ \\
\hline
\end{tabular}

Note: ${ }^{a}$ Widow, separate/divorced.

Abbreviations: OPD, outpatient department; ICU, intensive care unit; ORT, operating room theatre.

$(65 \%)$ were female and $54(35 \%)$ were male. Majority of study participants, $108(70.1 \%)$ with low back pain reported the gradual onset (over a period of time) of pain. Seventy-four $(48.1 \%)$ nurses reported they experienced low back pain which radiate to the low extremities (thigh and leg) (Table 4).

Among those with low back pain; 61 (39.6\%) intended to change their profession. Half of them reported they 76 (49.5\%) took analgesics to get relief for the pain. A total of 516 workdays were lost in the last three months due to low back pain (Table 5).

\section{Factors Associated with LBP}

In bivariable analysis, the socio-demographic variables (sex, years of experience, and working shift) were significantly associated with LBP. Lifestyle and personal factors such as smoking cigarette, chewing khat and back ergonomic practice
Table 2 Lifestyle and Personal Characteristics of Nurses Working at Public Hospitals in Harari Region and Dire Dawa City Administration, Eastern Ethiopia, $2018(n=404)$

\begin{tabular}{|l|l|l|l|}
\hline Variables & Category & Frequency & $\%$ \\
\hline Alcohol drinking & No & 304 & 75.2 \\
& Yes & 100 & 24.8 \\
\hline Duration of alcohol drinking & $<5$ years & 43 & 43 \\
& 5-10 years & 38 & 38 \\
& $>10$ years & 19 & 19 \\
\hline Smoking cigarette & No & 365 & 90.3 \\
& Yes & 39 & 9.7 \\
\hline Duration of smoking cigarette & $<5$ years & 20 & 51.3 \\
& $5-10$ years & 13 & 33.3 \\
& $>10$ years & 6 & 15.4 \\
\hline Regular physical exercise & No & 281 & 69.6 \\
& Yes & 123 & 30.4 \\
\hline Chewing khat & No & 325 & 80.4 \\
& Yes & 79 & 19.6 \\
\hline Duration of chewing khat & $<5$ years & 32 & 40.5 \\
& $5-10$ years & 33 & 41.8 \\
& $>10$ years & 14 & 17.7 \\
\hline Knowledge about back & No & 152 & 37.6 \\
ergonomics & Yes & 252 & 62.4 \\
\hline Back ergonomics practice (proper & No & 301 & 74.5 \\
back posture during the work) & Yes & 103 & 25.5 \\
\hline
\end{tabular}

were significantly associated with LBP. Furthermore, working in awkward posture, working when physically fatigued, pushing or pulling and lifting weight $>10 \mathrm{~kg}$ manually were workrelated variables found to be associated with LBP. Among the psychosocial variables; sleep disturbance due to work, felt little pleasure and helplessness in the last one month were significantly associated with the experience of LBP.

In multivariable regression analysis, only years of experience, lifting weight $>10 \mathrm{~kg}$ manually and working in awkward posture sustained their association with the outcome variable. Nurses who had more than 5 years of work experience [AOR: 3.13 (95\% CI: 1.29-7.60)], who lifted weight >10kg [AOR: 5.26 (95\% CI: 1.86-14.80)] manually, and who worked in awkward position or bad posture [AOR: 3.93 (95\% CI: 1.109-13.924)] were more likely to experience low back pain than their counterparts (Table 6).

\section{Discussion}

This study was conducted to assess the prevalence of low back pain (LBP) among nurses working in public health 
Table 3 Psychosocial Factors Among Nurses Working at Public Hospitals in Harari Region and Dire Dawa City Administration, Eastern Ethiopia, $2018(n=404)$

\begin{tabular}{|c|c|c|c|}
\hline Variables & Category & Frequency & $\%$ \\
\hline $\begin{array}{l}\text { Relaxation time/tea break at } \\
\text { work }\end{array}$ & $\begin{array}{l}\text { No } \\
\text { Yes }\end{array}$ & $\begin{array}{l}216 \\
188\end{array}$ & $\begin{array}{l}53.5 \\
46.5\end{array}$ \\
\hline Mental stress & $\begin{array}{l}\text { No } \\
\text { Yes }\end{array}$ & $\begin{array}{l}159 \\
245\end{array}$ & $\begin{array}{l}39.4 \\
60.6\end{array}$ \\
\hline Sleep disturbance & $\begin{array}{l}\text { No } \\
\text { Yes }\end{array}$ & $\begin{array}{l}202 \\
202\end{array}$ & $\begin{array}{l}50 \\
50\end{array}$ \\
\hline Job satisfaction & $\begin{array}{l}\text { Poor } \\
\text { Good }\end{array}$ & $\begin{array}{l}251 \\
153\end{array}$ & $\begin{array}{l}62.1 \\
37.9\end{array}$ \\
\hline Collaboration among nurse staff & $\begin{array}{l}\text { Poor } \\
\text { Good }\end{array}$ & $\begin{array}{l}35 \\
369\end{array}$ & $\begin{array}{l}8.7 \\
91.3\end{array}$ \\
\hline $\begin{array}{l}\text { Collaboration between nurses } \\
\text { and physicians }\end{array}$ & $\begin{array}{l}\text { Poor } \\
\text { Good }\end{array}$ & $\begin{array}{l}56 \\
348\end{array}$ & $\begin{array}{l}13.9 \\
86.1\end{array}$ \\
\hline $\begin{array}{l}\text { Collaboration among nurses and } \\
\text { other staff }\end{array}$ & $\begin{array}{l}\text { Poor } \\
\text { Good }\end{array}$ & $\begin{array}{l}45 \\
359\end{array}$ & $\begin{array}{l}11.1 \\
88.9\end{array}$ \\
\hline $\begin{array}{l}\text { Felt helplessness in the past one } \\
\text { month }\end{array}$ & $\begin{array}{l}\text { No } \\
\text { Yes }\end{array}$ & $\begin{array}{l}271 \\
133\end{array}$ & $\begin{array}{l}67.1 \\
32.9\end{array}$ \\
\hline $\begin{array}{l}\text { Felt little pleasure in the past } \\
\text { one month }\end{array}$ & $\begin{array}{l}\text { No } \\
\text { Yes }\end{array}$ & $\begin{array}{l}181 \\
223\end{array}$ & $\begin{array}{l}44.8 \\
55.2\end{array}$ \\
\hline
\end{tabular}

facilities in eastern Ethiopia. We found that almost one in four nurses reported that they experienced LBP in the preceding 12 months. Nurses who worked for more than five years, who reported lifting heavyweight $(>10 \mathrm{~kg})$ manually and who did not assume proper body posture (awkward posture) during care provision reported they suffered from LBP.

In this study, twelve months prevalence of low back pain was $38.1 \%$. In terms of the prevalence of LBP, the current finding is consistent with the study from Addis Ababa,
Table 4 Low Back Pain Experience Among Nurses Working at Public Hospitals in Harari Region and Dire Dawa City Administration, Eastern Ethiopia, 2018

\begin{tabular}{|c|c|c|c|}
\hline Variables & Category & Frequency & $\%$ \\
\hline $\begin{array}{l}\text { LBP in the past } 12 \\
\text { months }(n=404)\end{array}$ & $\begin{array}{l}\text { No } \\
\text { Yes }\end{array}$ & $\begin{array}{l}250 \\
154\end{array}$ & $\begin{array}{l}61.9 \\
38.1\end{array}$ \\
\hline $\begin{array}{l}\text { Experiencing LBP } \\
\text { currently }(n=404)\end{array}$ & $\begin{array}{l}\text { No } \\
\text { Yes }\end{array}$ & $\begin{array}{l}257 \\
147\end{array}$ & $\begin{array}{l}63.6 \\
36.4\end{array}$ \\
\hline Onset of LBP $(n=154)$ & $\begin{array}{l}\text { Gradual } \\
\text { Sudden }\end{array}$ & $\begin{array}{l}108 \\
46\end{array}$ & $\begin{array}{l}70.1 \\
29.9\end{array}$ \\
\hline $\begin{array}{l}\text { Pattern of radiation } \\
(n=154)\end{array}$ & $\begin{array}{l}\text { No radiation } \\
\text { Radiate to lower } \\
\text { extremities } \\
\text { Radiate to upper } \\
\text { extremities }\end{array}$ & $\begin{array}{l}60 \\
74 \\
20\end{array}$ & $\begin{array}{l}39 \\
48.1 \\
13\end{array}$ \\
\hline $\begin{array}{l}\text { Intensity of the pain } \\
(n=147)\end{array}$ & $\begin{array}{l}\text { Mild } \\
\text { Moderate } \\
\text { Severe }\end{array}$ & $\begin{array}{l}105 \\
31 \\
11\end{array}$ & $\begin{array}{l}72.5 \\
19.6 \\
8\end{array}$ \\
\hline Chronicity $(n=154)$ & $\begin{array}{l}\text { Sub-acute ( } 6 \text { weeks } \\
\text { to } 3 \text { months) } \\
\text { Chronic (>3 } \\
\text { months) }\end{array}$ & $\begin{array}{l}90 \\
64\end{array}$ & $\begin{array}{l}58.4 \\
41.6\end{array}$ \\
\hline
\end{tabular}

Abbreviation: LBP; low back pain.

Ethiopia $(45.8 \%),{ }^{27}$ and Ibadan, Nigeria $(44.1 \%) .{ }^{32}$ However, it is lower than the study from Egypt, Zigazig hospital $(79 \%),{ }^{23}$ Rwanda, Kanombe military hospital $(78 \%),{ }^{24}$ and Nigerian hospital $(73 \%) .{ }^{22}$ This may be due to the small sample size in those studies, differences of working environments or settings, participants pain reporting behavior, as well as variation in the level, frequency and duration of workload among nurses from those different settings.

This study also revealed that the prevalence of LBP is higher in females as compared to males. This is in line

Table 5 Consequence of Low Back Pain Among Nurses Working at Public Hospitals in Harari Region and Dire Dawa City Administration, Eastern Ethiopia, 2018

\begin{tabular}{|l|l|l|l|l|}
\hline \multirow{5}{*}{ Consequences of low back pain } & Variables & Category & Frequency & $\%$ \\
\cline { 3 - 5 } & Intention to change the profession & No & 93 & 60.4 \\
\cline { 3 - 5 } & & Yes & 61 & 39.6 \\
\cline { 2 - 5 } & Absenteeism from job & No & 68 & 44.2 \\
\cline { 3 - 5 } & & Yes & 86 & 55.8 \\
\cline { 2 - 5 } & Visited physician or physiotherapist & $\begin{array}{l}\text { No } \\
\text { Yes }\end{array}$ & 37 & 76 \\
\hline
\end{tabular}


Table 6 Factors Associated with Low Back Pain Among Nurses Working at Public Hospitals in Harari Region and Dire Dawa City Administration, Eastern Ethiopia, $2018(n=404)$

\begin{tabular}{|c|c|c|c|c|c|}
\hline \multirow[t]{2}{*}{ Variables } & \multirow[t]{2}{*}{ Category } & \multicolumn{2}{|c|}{ Low Back Pain } & \multicolumn{2}{|l|}{ OR $(95 \% \mathrm{Cl})$} \\
\hline & & No (\%) & Yes (\%) & COR & AOR \\
\hline \multirow[t]{2}{*}{ Sex } & Male & $125(69.8)$ & $54(30.16)$ & 1 & I \\
\hline & Female & $125(55.55)$ & $100(44.4)$ & $1.85(1.22-2.80)$ & $1.014(0.37-2.71)$ \\
\hline \multirow[t]{2}{*}{ Smoking cigarette } & No & $24 I(66.1)$ & 124(33.9) & I & I \\
\hline & Yes & $9(23.0)$ & $30(76.9)$ & $6.47(2.98-14.07)$ & $1.609(0.39-6.54)$ \\
\hline \multirow[t]{2}{*}{ Chewing khat } & No & $217(67.6)$ & 104(32.3) & I & I \\
\hline & Yes & $33(40)$ & $50(60)$ & $3.16(1.92-5.20)$ & $0.66(0.23-1.87)$ \\
\hline \multirow[t]{2}{*}{ Back ergonomic practice } & No & $202(67.1)$ & $99(32.8)$ & I & I \\
\hline & Yes & $48(46.6)$ & $55(53.3)$ & $2.33(1.48-3.68)$ & I.3I (0.50-3.42) \\
\hline \multirow[t]{2}{*}{ Years of experience } & $<5$ years & $176(74)$ & $62(26)$ & I & I \\
\hline & $\geq 5$ years & $74(44.5)$ & $92(55.4)$ & $3.52(2.3 \mathrm{I}-5.37)$ & $3.13(1.29-7.60)^{\mathrm{a}}$ \\
\hline \multirow[t]{2}{*}{ Work shift } & Day only & $58(67.4)$ & $28(32.5)$ & $\mathrm{I}$ & I \\
\hline & Day and Night & $192(60.3)$ & $126(39.6)$ & $1.35(0.82-2.25)$ & $1.69(0.61-4.68)$ \\
\hline \multirow[t]{2}{*}{ Working in awkward posture } & No & $22(24.4)$ & $69(75.6)$ & I & I \\
\hline & Yes & $8(12.6)$ & $55(87)$ & $3.75(1.37-10.28)$ & $3.93(1.10-13.92)^{b}$ \\
\hline \multirow[t]{2}{*}{ Working when physically fatigued } & No & $16(24)$ & $64(76)$ & I & I \\
\hline & Yes & $\mathrm{II}(15)$ & $63(85)$ & $1.68(1.68-3.72)$ & $0.56(0.16-1.91)$ \\
\hline \multirow[t]{2}{*}{ Pushing and pulling } & No & $19(21.1)$ & $7 I(78.8)$ & I & I \\
\hline & Yes & $8(12.5)$ & $56(87.5)$ & $2.16(0.91-5.12)$ & $\mathrm{I} .89(0.54-6.5 \mathrm{I})$ \\
\hline \multirow[t]{2}{*}{ Lifting weight $>10 \mathrm{~kg}$ manually } & No & $7(11.1)$ & $56(88.8)$ & I & I \\
\hline & Yes & $20(22)$ & $71(78)$ & $2.65(1.75-4.09)$ & $5.26(1.86-14.80)^{c}$ \\
\hline \multirow[t]{2}{*}{ Sleep disturbance due to work } & No & $\mid 44(7 \mid .2)$ & $58(28.7)$ & I & I \\
\hline & Yes & $106(53.3)$ & $96(46.6)$ & $2.24(1.49-3.39)$ & $0.84(0.31-2.23)$ \\
\hline \multirow[t]{2}{*}{ Felt helplessness in the past one month } & No & $126(58.6)$ & $89(41.3)$ & 1 & I \\
\hline & Yes & $124(65.6)$ & $65(34.3)$ & $0.74(0.49-1.1 \mathrm{I})$ & $0.57(0.23-1.39)$ \\
\hline \multirow[t]{2}{*}{ Felt little pleasure in doing things for the past one month } & No & $154(73.6)$ & $55(26.3)$ & I & I \\
\hline & Yes & $96(49.2)$ & $99(50.7)$ & $2.88(1.09-4.38)$ & $0.87(0.31-2.23)$ \\
\hline
\end{tabular}

Note: ${ }^{\mathrm{a}, \mathrm{b}, \mathrm{c}} \mathrm{p}$-value $<0.05$.

Abbreviations: $O R$, odds ratio; $A O R$, adjusted odds ratio; $C O R$, crude odds ratio.

with the previous studies in Nigerian and Ethiopian hospitals $(67.5 \%)^{3}$ and Saudi Arabia. ${ }^{19}$ Even though the reason for preponderance of female nurses for LBP is unclear, it might be due to their physiological factors such as menstruation and pregnancy. ${ }^{33-35}$ It could also be due to the structural or anatomical difference between male and female, sprain, and strain that LBP is common among females than males. ${ }^{36,37}$

A longer year of work experience was significantly associated with LBP. Nurses who had more than 5 years' experience were 3 times more likely to experience LBP than their counterparts. Similar findings were obtained from Adama and Gonder, Ethiopia. ${ }^{2,26}$ This finding is also consistent with the study findings reported from Turkey, Iran,

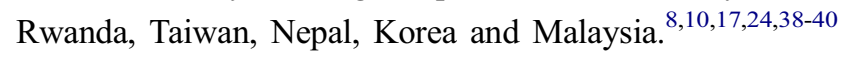
This might be due to the direct patient care activities which are physically demanding, and escalates the LBP with repetitive exposure to the physical and psychosocial hazards. ${ }^{10}$ However, other study findings from Egypt, Thailand, India and Turkey show no significant association between LBP and nurses' work experience. ${ }^{41-44}$

In the current study, nurses who manually lifted a weight of greater than $10 \mathrm{~kg}$ were more likely to experience LBP as compared to those who did not. This finding 
is supported by the study from Makah, Saudi Arabia, ${ }^{18}$ from Doha, Qatar, ${ }^{9}$ and Ankara, Turkey. ${ }^{16}$ It is also in line with the findings of studies in Tunisia ${ }^{25}$ and Zigazig university hospital, Egypt. ${ }^{23}$ This association may be related to inappropriate use of body mechanics during weight lifting and it shed light on the importance of some educational intervention programs for nurses on how to lift objects. On the other hand, lifting weight was not significantly associated with LBP from studies in $\mathrm{Yemen}^{20}$ and Malaysia. ${ }^{8}$

Working in awkward posture was also significantly associated with the experience of LBP. Nurses who worked in awkward posture were more likely to have low back pain, which is comparable with the study from Saudi Arabia ${ }^{18}$ and Malaysia. ${ }^{4}$ A similar finding was reported from a study in Nigeria. ${ }^{22}$ This may be due to the similarity of nurse's activities anywhere which needs frequent bending, twisting and leaning forward or backward. In contrast to the current study finding, there was no association between LBP and awkward posture according to the study from Tunisia. ${ }^{25}$

Even though not significantly associated with low back pain in the current study, literatures revealed that the psychosocial factors progressively affect the physical health leading to $\mathrm{LBP}^{45,46}$ and may exacerbate muscle tension causing feeling of pain. It was also described in a previous study that psychosocial factors are associated with the experience of LBP in nursing personnel. ${ }^{10}$ Stress and anxiety were reported to be the main psychosocial factors that lead to LBP. ${ }^{47,48}$

The strength of this study is the use of a standard questionnaire. However, recall bias might have been introduced since the information on the past one year experience of low back pain highly depends on the respondents' memory.

\section{Conclusions}

About two in five nurses working in public hospitals of Harari region and Dire Dawa city administration were suffering from low back pain. This could fuel up the burden of human resource shortage in the field of nursing. Long duration of work experience, lifting weight $>10 \mathrm{~kg}$ manually and working in awkward posture at work were important factors that contributed to the occurrence of LBP. Those modifiable risk factors can be prevented through tailored intervention to retain experienced nurse staff. Future studies might need to include samples from multi-centers.

\section{Ethical Approval and Informed Consent}

Ethical clearance was obtained from the Institutional Health Research Ethics Review Committee (IHRERC) of the College of Health and Medical Sciences, Haramaya University. Support letter was written to all public hospitals where the study was conducted.

Individual informed voluntary written consent was obtained from each study participant. The respondents were assured of confidentiality by excluding their names during the data collection. They were also well informed that they have full right to refuse to participate and/or withdraw from the study at any time without any precondition.

\section{Acknowledgments}

We are thankful to the study participants, data collectors and field supervisors for their contribution to this study. We would also like to appreciate Haramaya University for funding this study.

\section{Author Contributions}

All authors made substantial contributions to conception and design, acquisition of data, or analysis and interpretation of data; took part in drafting the article or revising it critically for important intellectual content; gave final approval of the version to be published; and agree to be accountable for all aspects of the work.

\section{Funding}

Haramaya University has provided financial support for this study. We declare that the funding body has no role in the designing of the study, in the collection, analysis and interpretation of the data, in the writing of this manuscript and in the decision to submit for publication.

\section{Disclosure}

The authors declare that there is no conflict of interest to declare for publication of this study.

\section{References}

1. Duthey B. Priority medicines for Europe and the world. A public health approach to innovation. WHO Background Paper. 2013;6.

2. Yitayeh A, Mekonnen S, Fasika S, Gizachew M. Annual prevalence of self-reported work related musculoskeletal disorders and associated factors among nurses working at Gondar Town Governmental Health Institutions, Northwest Ethiopia. Emerg Med (Los Angel). 2015;5 (227):2. 
3. Sikiru L, Shmaila H. Prevalence and risk factors of low back pain among nurses in Africa: Nigerian and Ethiopian specialized hospitals survey study. East Afr J Public Health. 2009;6(1). doi:10.4314/eajph. v6i1.45737

4. Samat RA, Shafei MN, Yaacob NA, Yusoff A. Prevalence and associated factors of back pain among dental personnel in North-Eastern State of Malaysia. Int J Collab Res Intern Med. 2011;3(7).

5. Murray CJ, Abraham J, Ali MK, et al. The state of US health, 1990-2010: burden of diseases, injuries, and risk factors. JAMA. 2013;310(6):591-606. doi:10.1001/jama.2013.13805

6. Olivier B, Mudzi W, Mamabolo M, Becker P. The association between psychological stress and low back pain among district hospital employees in Gauteng, South Africa. S Afr J Physiother. 2010;66(2):17-21. doi:10.4102/sajp.v66i2.63

7. Mohseni-Bandpei MA, Fakhri M, Bargheri-Nesami M, AhmadShirvani M, Khalilian AR, Shayesteh-Azar M. Occupational back pain in Iranian nurses: an epidemiological study. $\mathrm{Br} J$ Nurs. 2006;15(17):914-917. doi:10.12968/bjon.2006.15.17.21904

8. Thon CC, Feng PKJ, Lian CW. Risk factors of low back pain among nurses working in Sarawak General Hospital. Health. 2016;7 (1):13-24.

9. Abolfotouh SM, Mahmoud K, Faraj K, Moammer G, ElSayed A, Abolfotouh MA. Prevalence, consequences and predictors of low back pain among nurses in a tertiary care setting. Int Orthop. 2015;39(12):2439-2449. doi:10.1007/s00264-015-2900-x

10. Feng C-K, Chen M-L, Mao I-F. Prevalence of and risk factors for different measures of low back pain among female nursing aides in Taiwanese nursing homes. BMC Musculoskelet Disord. 2007;8(1):52. doi:10.1186/1471-2474-8-52

11. Al Dajah S, Al Daghdi A. Prevalence and risk factors of low back pain among nurses in Sudayr region. Eur Sci J. 2013;9(33).

12. Adhikari S, Dhakal G. Prevalent causes of low back pain and its impact among nurses working in Sahid Gangalal National Heart Centre. J Nepal Health Res Counc. 2015.

13. Maul I, Läubli T, Klipstein A, Krueger H. Course of low back pain among nurses: a longitudinal study across eight years. Occup Environ Med. 2003;60(7):497-503. doi:10.1136/oem.60.7.497

14. Alexopoulos EC, Burdorf A, Kalokerinou A. A comparative analysis on musculoskeletal disorders between Greek and Dutch nursing personnel. Int Arch Occup Environ Health. 2006;79(1):82-88. doi: 10.1007/s00420-005-0033-z

15. Lorusso A, Bruno S, L'abbate N. A review of low back pain and musculoskeletal disorders among Italian nursing personnel. Ind Health. 2007;45(5):637-644. doi:10.2486/indhealth.45.637

16. Karahan A, Kav S, Abbasoglu A, Dogan N. Low back pain: prevalence and associated risk factors among hospital staff. $J$ Adv Nurs. 2009;65(3):516-524. doi:10.1111/j.1365-2648.2008.04905.x

17. June KJ, Cho SH. Low back pain and work-related factors among nurses in intensive care units. J Clin Nurs. 2011;20(3-4):479-487. doi:10.1111/j.1365-2702.2010.03210.x

18. Homaid MB, Abdelmoety D, Alshareef W, et al. Prevalence and risk factors of low back pain among operation room staff at a Tertiary Care Center, Makkah, Saudi Arabia: a cross-sectional study. Ann Occup Environ Med. 2016;28(1):1. doi:10.1186/s40557-016-0089-0

19. Keriri H. Prevalence and risk factors of low back pain among nurses in operating rooms, Taif, Saudi Arabia. Am J Res Commun. 2013;1 (11):25

20. Ghilan K, Al-Taiar A, Al Yousfi N, Al Zubaidi R, Awadh I, AlObeyed Z. Low back pain among female nurses in Yemen. Int J Occup Med Environ Health. 2013;26(4):605-614. doi:10.2478/ s13382-013-0124-0

21. Hinmikaiye CD, Bamishaiye EI. The incidence of low back pain among theatre nurses: a case study of University of Ilorin and Obafemi Awolowo University Teaching Hospital. Int J Nurs Sci. 2012;2(3):23-28. doi:10.5923/j.nursing.20120203.02
22. Sikiru L, Hanifa S. Prevalence and risk factors of low back pain among nurses in a typical Nigerian hospital. Afr Health Sci. 2010;10 (1):26.

23. Abou El-Soud AM, El-Najjar AR, El-Fattah NA, Hassan AA. Prevalence of low back pain in working nurses in Zagazig University Hospitals: an epidemiological study. Egypt Rheumatol Rehabil. 2014;41(3):109. doi:10.4103/1110-161X.140525

24. Lela M, Frantz JM. Physical activity among nurses in Kanombe Military Hospital. S Afr J Physiother Rehabil Sci. 2012;4(1-2):63-66. doi:10.4314/ajprs.v4i1-2.10

25. Bejia I, Younes M, Jamila HB, et al. Prevalence and factors associated to low back pain among hospital staff. Joint Bone Spine. 2005;72(3):254-259. doi:10.1016/j.jbspin.2004.06.001

26. Abebe AD, Gebrehiwot EM, Lema S, Abebe TW. Prevalence of low back pain and associated risk factors among Adama Hospital Medical College Staff, Ethiopia. Eur J Prev Med. 2015;3(6):188-192. doi:10.11648/j.ejpm.20150306.15

27. Belay MM, Worku A, Gebrie SA, Wamisho B. Epidemiology of low back pain among nurses working in public hospitals of Addis Ababa, Ethiopia. East Cent Afr J Surg. 2016;21(1):113-131. doi:10.4314/ ecajs.v21i1.139040

28. Bener A, Dafeeah EE, Alnaqbi K. Prevalence and correlates of low back pain in primary care: what are the contributing factors in a rapidly developing country. Asian Spine J. 2014;8(3):227. doi:10.4184/asj.2014.8.3.227

29. Kuorinka I, Jonsson B, Kilbom A, et al. Standardised nordic questionnaires for the analysis of musculoskeletal symptoms. Appl Ergon. 1987;18(3):233-237. doi:10.1016/0003-6870(87)90010-X

30. Doshi P. How to assess pain. Suppl J Assoc Physicians India. 2015.

31. Krismer M, Van Tulder M. Low back pain (non-specific). Best Pract Res Clin Rheumatol. 2007;21(1):77-91. doi:10.1016/j.berh.2006. 08.004

32. Tinubu BM, Mbada CE, Oyeyemi AL, Fabunmi AA. Work-related musculoskeletal disorders among nurses in Ibadan, South-west Nigeria: a cross-sectional survey. BMC Musculoskelet Disord. 2010;11(1):12. doi:10.1186/1471-2474-11-12

33. Smith DR, Mihashi M, Adachi Y, et al. Menstrual disorders and their influence on low back pain among Japanese nurses. Ind Health. 2009;47(3):301-312. doi:10.2486/indhealth.47.301

34. Wang S-M, Dezinno P, Maranets I, Berman MR, Caldwell-Andrews AA, Kain ZN. Low back pain during pregnancy: prevalence, risk factors, and outcomes. Obstet Gynecol. 2004;104(1):65-70. doi:10.1097/01.AOG.0000129403.54061.0e

35. Borg-Stein J, Dugan SA. Musculoskeletal disorders of pregnancy, delivery and postpartum. Phys Med Rehabil Clin N Am. 2007;18 (3):459-476. doi:10.1016/j.pmr.2007.05.005

36. Barber-Westin SD, Noyes FR, Galloway M. Jump-land characteristics and muscle strength development in young athletes: a gender comparison of 1140 athletes 9 to 17 years of age. Am J Sports Med. 2006;34(3):375-384. doi:10.1177/0363546505281242

37. Hoy D, Bain C, Williams G, et al. A systematic review of the global prevalence of low back pain. Arthritis Rheum. 2012;64 (6):2028-2037. doi:10.1002/art.34347

38. Lin P-H, Tsai Y-A, Chen W-C, Huang S-F. Prevalence, characteristics, and work-related risk factors of low back pain among hospital nurses in Taiwan: a cross-sectional survey. Int J Occup Med Environ Health. 2012;25(1):41-50. doi:10.2478/s13382-012-0008-8

39. Shubham S, Yadav R. Prevalence of low backache in practicing dentists of Eastern region of Nepal. J Univers Coll Med Sci. 2013;1 (4):29-32. doi:10.3126/jucms.v1i4.9570

40. Şimşek Ş, Yağcı N, Şenol H. Prevalence and risk factors of low back pain among health-care workers in Denizli. Agri. 2017;29(2):71-78.

41. Sritipsukho P, Siripakarn Y. Prevalence and risk factors of low back pain among the university staff. J Med Assoc Thai. 2010;93(suppl 7): S142-S1S8. 
42. Hegazy A, Salama B, Elgaml A, Alzyat AR. Association of low back pain with vitamin D deficiency and other common risk factors: a hospital based case-control study. Eur J Preventive Med. 2015;3 (1):1-5. doi:10.11648/j.ejpm.20150301.11

43. Shah S, Dave B. Prevalence of low back pain and its associated risk factors among doctors in Surat. Int J Heal Sci Res. 2012;2:91-102.

44. Altinel L, Kose KC, Ergan V, et al. The prevalence of low back pain and risk factors among adult population in Afyon region, Turkey. Acta Orthop Traumatol Turc. 2008;42(5):328-333. doi:10.3944/ AOTT.2008.328
45. Yilmaz E, Dedeli O. Effect of physical and psychosocial factors on occupational low back pain. 2014.

46. Tosunoz IK, Oztunc G. Low back pain in nurses. Int J Caring Sci. 2017; 10:1728-1732.

47. Moussa MMM, El-Ezaby HH, El-Mowafy RI. Low back pain and coping strategies' among nurses in Port Said City, Egypt. J Nurs Educ Pract. 2015;5(7):55-62.

48. Wong T, Teo N, Kyaw M. Prevalence and risk factors associated with low back among health care providers in a District Hospital. Malays Orthop J. 2010;4(2):23-28. doi:10.5704/MOJ.1007.004

\section{Publish your work in this journal}

The Journal of Pain Research is an international, peer reviewed, open access, online journal that welcomes laboratory and clinical findings in the fields of pain research and the prevention and management of pain. Original research, reviews, symposium reports, hypothesis formation and commentaries are all considered for publication. The manuscript

Submit your manuscript here: https://www.dovepress.com/journal-of-pain-research-journal management system is completely online and includes a very quick and fair peer-review system, which is all easy to use. Visit http:// www.dovepress.com/testimonials.php to read real quotes from published authors. 